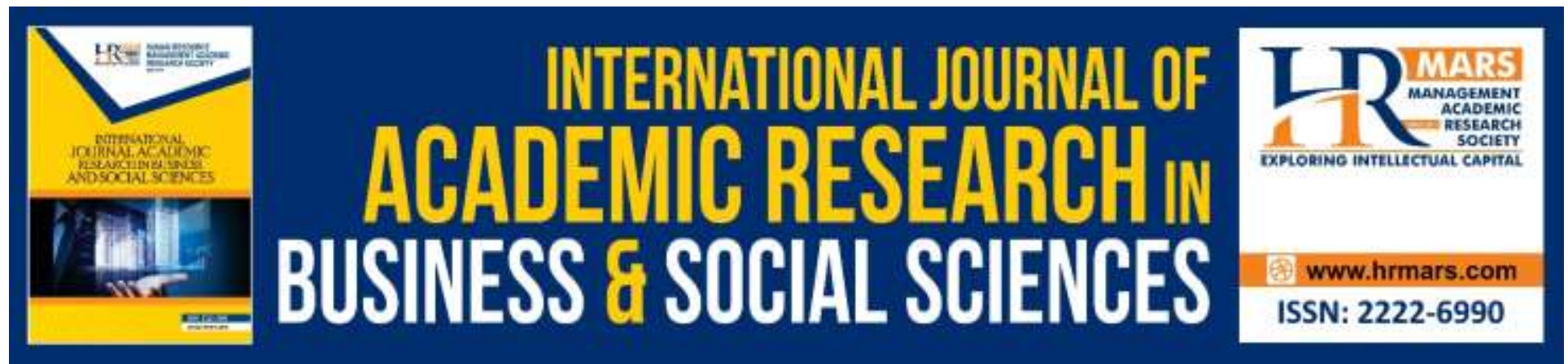

\title{
Land Allocation Approach for the Non-Registered Proprietor Flood Victims in Kuala Krai
}

Mohamad Haizam Mohamed Saraf, Thuraiya Mohd and Siti Fairuz Che Pin

To Link this Article: http://dx.doi.org/10.6007/IJARBSS/v8-i1/4068

DOI:10.6007/IJARBSS/v8-i1/4068

Received: 02 Dec 2017, Revised: 07 Jan 2018, Accepted: 16 Jan 2018

Published Online: 18 Jan 2018

In-Text Citation: (Saraf, Mohd, \& Pin, 2018)

To Cite this Article: Saraf, M. H. M., Mohd, T., \& Pin, S. F. C. (2018). Land Allocation Approach for the NonRegistered Proprietor Flood Victims in Kuala Krai. International Journal of Academic Research in Business and Social Sciences, 8(1), 938-953.

\section{Copyright: @ 2018 The Author(s)}

Published by Human Resource Management Academic Research Society (www.hrmars.com)

This article is published under the Creative Commons Attribution (CC BY 4.0) license. Anyone may reproduce, distribute, translate and create derivative works of this article (for both commercial and non-commercial purposes), subject to full attribution to the original publication and authors. The full terms of this license may be seen at: http://creativecommons.org/licences/by/4.0/legalcode

Vol. 8, No.1, January 2018, Pg. $938-953$

Full Terms \& Conditions of access and use can be found at http://hrmars.com/index.php/pages/detail/publication-ethics 


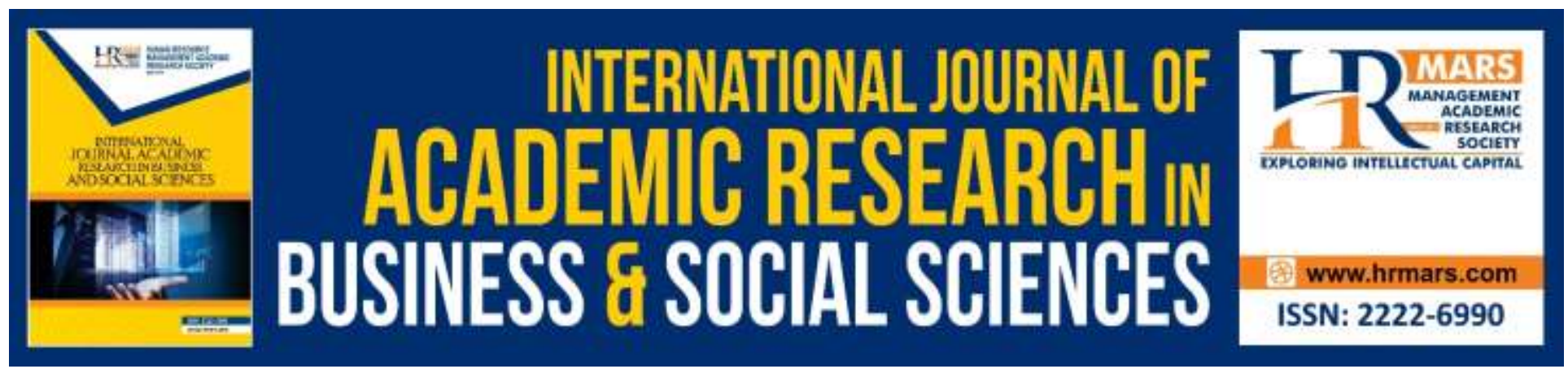

\title{
Land Allocation Approach for the Non-Registered Proprietor Flood Victims in Kuala Krai
}

\section{Mohamad Haizam Mohamed Saraf, Thuraiya Mohd and Siti Fairuz Che Pin}

Faculty of Architecture, Planning and Surveying, Universiti Teknologi MARA, Perak Branch, Seri Iskandar Campus, 32610 Bandar Seri Iskandar, Perak, Malaysia

\begin{abstract}
The purpose of this research is to provide land allocation approach for the non registered proprieotor flood victims in Kuala Krai, Malaysia. Twelve (12) experts from the perspectives of land law, policies and administrations were interviewed by using semi-structured interview to gauge their perceptions in the possible land allocation approach for the non-registered proprietor flood victims. The experts recommended the state alienation approach to allocate land for the purpose of emergency, temporary shelters and new permanent house. This approach will ensure that the land required to shelter disaster victims irrespective of their land titles in post disaster house construction can prevent long term displacement after disaster. The findings from this research will provide significant input to the federal, state and local governments for effective planning and policy making in Total Disaster Risk Management as a holistic approach in managing the impact from disasters. The input will also help the governments to successfully provide a better quality of life to the affected people.
\end{abstract}

Keywords: Flood Victims, Non-Registered Proprietors, Land Ownership Constraints, Land Allocation Approach

\section{Introduction}

The end of 2014 floods in Kelantan was among the worst in Malaysia. It was reported by the Kelantan Flood Disaster Committee that the highest number of destroyed houses in Kelantan was in Kuala Krai with 1,850 units. Following a disaster, recovery effort will be executed. Although the federal government had promised 1,255 units of new permanent houses to the victims, many units are still delayed because of land ownership constraints (Public Works Department [PWD], 2016). Nearly three (3) years later, some of the flood victims without land ownership are still living in the temporary shelters (National Disaster Management [NaDMA], 2016). According to PWD, the procedure to build the new permanent house is the victims must show proof of land ownership. If the land title states clearly the victim's name as the registered proprietor, the issue of land ownership is not an issue and the new permanent house can be built on the victim's land. 
Unfortunately, many flood victims were non-registered proprietors and they will have to continue living in the temporary shelters and seek help from the Non-Governmental Organisations (NGOs) for land (Mohd et al, 2017). Temporary shelters and the new permanent house construction for the landless need new land.

There is often a lack of authority to do so. Thus, insufficient land allocation slows down the post-disaster recovery efforts (Thomas, 2015). Although the governments, agencies and public were heavily involved in the post disaster recovery an effort, the current disaster management planning is still could not solve the non-registered proprietor flood victims and slows down the process. The question arise is 'how to provide land for the non-registered flood victims in Kuala Krai, Kelantan?". Motivated by the need to look into immediate action in the future and for justice to the non-registered proprietor flood victims, this research attempts to recommend the land allocation approach for them.

\section{Literature Review}

\section{Reviewing the International Practices on Land Allocation Approach}

Fitzpatrick (2008) states that in the post disaster settings, land for temporary buildings, emergency and new permanent housing must be at a premium. Furthermore, Leckie (2011) stresses the vitality to acquire new land following certain types of disasters, most notably severe flooding and tsunamis, because considerable amounts of land can be physically lost hence making return impossible.

It is necessary to look into the international land allocation approach to improve the postdisaster management in Malaysia. Below table shows the approach use by several countries in allocating land for emergency, shelters and post disaster house construction.

\begin{tabular}{lcccc}
\hline Author(s) & $\begin{array}{c}\text { Rwanda } \\
\text { Republic }\end{array}$ & $\begin{array}{l}\text { Sandra Carrasco, } \\
\text { Chiho Ochiai and } \\
\text { Kenji Okazaki }\end{array}$ & $\begin{array}{c}\text { Bangladesh } \\
\text { Water } \\
\text { Development } \\
\text { Board }\end{array}$ & $\begin{array}{c}\text { Islamic Republic of } \\
\text { Pakistan }\end{array}$ \\
\hline $\begin{array}{l}\text { Year of } \\
\text { Publication } \\
\begin{array}{l}\text { Country of } \\
\text { Study }\end{array}\end{array}$ & Rwanda & \multicolumn{1}{c}{ Philippines } & Bangladesh & Pakistan \\
$\begin{array}{l}\text { Title of } \\
\text { Research }\end{array}$ & $\begin{array}{l}\text { Resettlement } \\
\text { Policy } \\
\text { Framework: } \\
\text { Republic of } \\
\text { Rwanda }\end{array}$ & $\begin{array}{l}\text { Disaster Induced } \\
\text { Resettlement: Multi- } \\
\text { Stakeholder } \\
\text { interactions } \\
\text { and decision making } \\
\text { following Tropical } \\
\text { Storm Washi in } \\
\text { Cagayan } \\
\text { de Oro, Philippines }\end{array}$ & $\begin{array}{l}\text { Resettlement } \\
\text { Framework in } \\
\text { Bangladesh: Flood } \\
\text { and Riverbank } \\
\text { Erosion Risk } \\
\text { Management } \\
\text { Investment } \\
\text { Program }\end{array}$ & $\begin{array}{l}\text { Reconstruction } \\
\text { Project }\end{array}$ \\
\hline
\end{tabular}


INTERNATIONAL JOURNAL OF ACADEMIC RESEARCH IN BUSINESS AND SOCIAL SCIENCES Vol. 8, No.1, January 2018, E-ISSN: 2222-6990 @ 2018 HRMARS

\begin{tabular}{|c|c|c|c|c|}
\hline $\begin{array}{l}\text { Land } \\
\text { Allocation } \\
\text { Approach }\end{array}$ & $\begin{array}{l}\text { The } \\
\text { Expropriation } \\
\text { Law provides } \\
\text { land for } \\
\text { public } \\
\text { interests; } \\
\text { that includes } \\
\text { resettlement } \\
\text { projects }\end{array}$ & $\begin{array}{l}\text { Land Banking. The } \\
\text { local government } \\
\text { already had allocated } \\
\text { land under } \\
\text { Relocation Draft Plan } \\
\text { and had purchased } \\
\text { land for housing } \\
\text { informal settlers and } \\
\text { evacuees for } \\
\text { resettlement sites. }\end{array}$ & $\begin{array}{l}\text { Land for } \\
\text { resettlement is } \\
\text { made available } \\
\text { through land } \\
\text { acquisition under } \\
\text { the Acquisition } \\
\text { and Requisition of } \\
\text { Immovable } \\
\text { Property } \\
\text { Ordinance II } \\
\text { (1982). }\end{array}$ & $\begin{array}{l}\text { The Pakistan Land } \\
\text { Acquisition Law } 1894 \\
\text { (amendments) } \\
\text { enables the federal } \\
\text { and provincial } \\
\text { governments to } \\
\text { acquire land on an } \\
\text { emergency basis. }\end{array}$ \\
\hline
\end{tabular}

Table 1: Matrix of Selected Land Allocation Approaches from other Countries

Note: Selected Resettlement Policies from Several Countries

In Rwanda, according to the National Land Policy, all Rwandese enjoy the same rights of access to land, without discrimination against women or any other vulnerable persons. Vulnerable persons in disaster case are referring to the affected persons; they are eligible for resettlement under the government projects. All those affected persons whose family land/ house/ business premises/services or buildings that are located within the identified disaster prone areas will be acquired and will be compensated accordingly under the resettlement projects. It includes both the title holder and rental or lease holders. The allocation of land is made available with the compliance of the procedure laid under Article 12 of The Expropriation Law. It stipulates that The Expropriation Law provides land for public interests; which includes resettlement projects as laid down under Article 5 of the Law (Rwanda Republic, 2016).

While in Bangladesh, land acquisition is used to allocate land for resettlement projects. The policies and guidelines also provide resettlement assistance to all the affected persons, irrespective of their titles to land based on the Jamuna Project model. The policy also states that the lack of legal documents for customary rights of occupancy or titles shall not affect eligibility of the affected persons in the resettlement projects. All affected persons as mentioned in the policies and guidelines will be eligible for compensation and assistance to be provided by the resettlement projects.

In Philippines, the local governments had already draft a relocation plan and purchased lands for housing the evacuees for temporary shelter or new permanent house (Carrasco, S; Ochiai and Okazaki, 2016). Moreover, private institutions also donate land for the purpose of providing land for emergency temporary shelters. It was a great advantage to have land available before disaster strikes although there are some issues relating to the location of the resettlement sites which is away from the cities. The allocated land allows quick start of the construction of new permanent houses to the evacuees, especially land squatters.

Land Acquisition Act 1984 of Pakistan (with successive amendments) enables the government to acquire land for emergency basis that includes resettlement areas for disaster evacuees who lost their houses to the disaster. The land is allocated through acquisition following 
a disaster and the resettlement project is estimated to complete within two-year time. However, only titled land owners or customary rights holder is eligible for the resettlement project.

From the review of land allocation policies from several countries, there are two approaches in the land allocation for emergency, temporary shelter and new permanent house for the non-registered proprietor flood victims. The first approach is the allocation of land through land acquisition by the government and the second approach is through land alienation by the government.

\section{Malaysia Approach in Tackling the Post Tsunamis House Construction}

As land allocation policy is yet to be known in our country's disaster management, the 2004 Tsunamis approach for post disaster house construction was reviewed. The worst affected areas were in Penang and Kedah which involved 328 units of destroyed houses and regrettably took 52 lives (Ong, 2007). Post disaster house assistance were funded under the National Disaster Relief Fund, however land ownership constraints among the tsunamis victims deliberate the construction of the houses. The ways the governments and Non-governmental Organisations tackling the issue of non-land owners are summarized in Table 2.

\begin{tabular}{|c|c|c|c|}
\hline Location & $\begin{array}{l}\text { Tanjung } \\
\text { Penang }\end{array}$ & Kuala Muda, Kedah & Langkawi, Kedah \\
\hline $\begin{array}{l}\text { The Approach Used } \\
\text { in the Post Tsunamis } \\
\text { House Construction } \\
\text { for Victims With } \\
\text { Land Ownership }\end{array}$ & $\begin{array}{l}\text { A new post disaster } \\
\text { house funded by the } \\
\text { Federal Government } \\
\text { under the National } \\
\text { Disaster Relief Fund } \\
\text { built on the land they } \\
\text { owned. }\end{array}$ & $\begin{array}{l}\text { A new post disaster } \\
\text { house funded by the } \\
\text { Federal Government } \\
\text { under the National } \\
\text { Disaster Relief Fund } \\
\text { built on the land they } \\
\text { owned. }\end{array}$ & $\begin{array}{l}\text { A new post disaster } \\
\text { house funded by the } \\
\text { Federal Government } \\
\text { under the National } \\
\text { Disaster Relief Fund } \\
\text { built on the land they } \\
\text { owned. }\end{array}$ \\
\hline $\begin{array}{l}\text { The Approach Used } \\
\text { in the Post Tsunamis } \\
\text { House Construction } \\
\text { for Victims Without } \\
\text { Land Ownership }\end{array}$ & $\begin{array}{l}\text { State government } \\
\text { gives land and a few } \\
\text { blocks of low cost } \\
\text { apartments donated } \\
\text { by public fund raised. }\end{array}$ & $\begin{array}{l}\text { State government } \\
\text { provides land with a } \\
\text { basic low cost house } \\
\text { for the renters and } \\
\text { informal settlers. }\end{array}$ & $\begin{array}{l}\text { Not applicable as all } \\
\text { the victims were } \\
\text { registered owners. }\end{array}$ \\
\hline
\end{tabular}

Table Error! No text of specified style in document.: Malaysia Current Approach in Post Disaster House Construction

Source: Ong (2007), National Disaster Management Agency (2015) \& Public Works Department (2015)

In Penang, as there was no land allocated for emergency purpose, the government gave land for the resettlement project to help 133 displaced persons without land ownership. To make the land adequate to include all the displaced persons, low cost apartments were constructed as the land size was not able to house 133 landed properties. The cost of the apartments was funded by public donations (Horton et al., 2008). The total cost for the land, apartments to accommodate the 133 victims with land ownership constraints, basic utilities and facilities were RM80 million. 
Similarly in Kota Kuala Muda, to accommodate the non-land owners tsunamis victims, the government gave a piece of land and a basic house for them which costs RM20 million, including the cost of utilities, sewage plant, sewerage and other facilities. In Langkawi however, all the victims who had lost their houses to tsunamis were registered owners. Therefore, the construction of the post disaster house was not an issue.

The costs to accommodate all the 328 non land owners' victims was approximately about RM100 million. The delay to provide new permanent house for the flood victims of Kuala Krai was simply because the scale of destruction was bigger which involved 1,850 units of destroyed houses. With no land allocated for such purpose in pre-disaster planning, the reconstruction effort took far longer than necessary to be completed. Even after 3 years after the flood, there are still flood victims who are living in temporary shelters and waiting for the post disaster house assistance. The need of land allocation policy is obligatory as a solution in the post disaster house construction (Leckie, 2011; Thomas, 2015; Carassco, et. al, 2016).

\section{Land Allocation Approach in Malaysia Context}

There is insufficient policy regarding land allocation for emergency purposes in Malaysia's law simply because Malaysia seldom has major disaster events (National Disaster Management Agency, n.d.). The major flood that hit Kelantan in December 2014 should be taken seriously in improving post-disaster recovery efforts in Malaysia. Through several reviews on the existing land allocation policies from different countries, it seems appropriate for Malaysia to consider land allocation policy in the flood disaster management under the land policy and land law. There are two approaches to make land available before a disaster strikes; a provision under the state power to dispose land as stipulated under Section 42 of the National Land Code 1965 and the acquisition of land as laid down under the Land Acquisition Act 1960.

In Malaysia, land matters are under the purview of the state government as stipulated under the Ninth Schedule, List 2, Item 2 of the Federal Constitution (Federal Constitution, p.272). The state authority has the right to gazette any state land for public purpose with accordance to Section 62 of the National Land Code 1965 [NLC] (NLC, p.79). In terms of legal aspect, it is all right for the state authority to gazette any state land for public purpose, in this case the land allocation for disaster reconstruction and rehabilitation phase.

Federal and state authorities also have the right to acquire land through Land Acquisition Act [LAA] 1960 if necessary. As provided under Section 3 (c) of the LAA 1960, governments can acquire private land for mining, residential, agriculture, commercial or industrial purposes. The only issue is the interpretation of residential purpose does not further explain that the land can be acquired for emergency, temporary shelters or new permanent houses under residential purposes. Established cases like Petaling Rubber Estates Ltd. against Pemungut Hasil Tanah Kedah, Pemungut Hasil Tanah Kuantan against Nor Cahaya Bt Ab. Majid and Oriental Rubber and Oil Palm Sdn. Bhd only discussed the acquisition involved were for the purpose of low cost residential housing schemes. If the land can be acquired for emergency, temporary shelters and post-disaster new permanent houses construction purposes, people who their lands are acquired 
cannot question the intention to acquire, except in the matters of adequate compensation (Husin, 1996).

From the legal aspects (Federal Constitution, National Land Code and Land Acquisition Act), the state authority has the ability to make land available for resettlement purposes in accordance to the National Land Code 1965, and any larger institutions can acquire land for acquisition if the interpretation of Section 3(c) of the LAA 1960 includes emergency nature such as disasters. Then, land allocation can be made available before a disaster strikes. This will accelerate the process in providing new permanent houses for flood victims, regardless if the flood victims have land ownership or are landless.

In order to avoid recreating or worsening the extent of their less fortunate condition, assistance in allocating land for the poor and vulnerable people must not be overlooked (World Bank, 2013). The land allocation policy's objective must be designed and implemented in any resettlement projects in a way that fosters full respect for the vulnerable groups - the poor, disabled and non-registered proprietor flood victims. This will provide them with culturally appropriate aid, social and economic benefits, and avoid adverse impacts or worsen their current condition (Weerasinghe, 2014).

\section{Research Methodology}

This research applies the qualitative approach in order to gauge the recommendations of the land allocation approach for the non-registered proprietor flood victims from the experts for the purpose of emergency, temporary shelters and new permanent house in the post-disaster management. Data were gathered through in-depth interview by using semi-structured interview. The characteristics of semi-structured interview are it is focused on the respondents' experiences regarding the research topic and it takes place with respondents known to have been involved in a particular experience (Onwuegbuzie, A. J., Leech, N. L. and Collins, K. M., 2012). The characteristics of the participants are shown in Table 3.

\begin{tabular}{|l|c|}
\hline \multicolumn{1}{|c|}{ Variables } & Frequency \\
\hline Age of Participant & 3 \\
\hline 36 to 40 years & 3 \\
\hline 41 to 45 years & 6 \\
\hline Above 46 years & 12 \\
\hline Gender & 0 \\
\hline Male & \\
\hline Female & 1 \\
\hline Highest level of education & 1 \\
\hline Diploma & 3 \\
\hline Advance Diploma & 1 \\
\hline Bachelor Degree & 6 \\
\hline Master Degree & \\
\hline Doctor in Philosophy & \\
\hline
\end{tabular}


INTERNATIONAL JOURNAL OF ACADEMIC RESEARCH IN BUSINESS AND SOCIAL SCIENCES

Vol. 8, No.1, January 2018, E-ISSN: 2222-6990 @ 2018 HRMARS

\begin{tabular}{|l|l|}
\hline Profession & 4 \\
\hline Professor & 1 \\
\hline Associate Professor & 1 \\
\hline Legal Advisor & 1 \\
\hline $\begin{array}{l}\text { Director of Strategic Programme } \\
\text { Development }\end{array}$ & 1 \\
\hline Deputy Director & 1 \\
\hline Deputy District Officer & 1 \\
\hline Land Officer & 2 \\
\hline Land Officer Assistant & 2 \\
\hline Length of Industrial Experience & 3 \\
\hline 10 years & 3 \\
\hline 11 to 15 years & 4 \\
\hline 16 to 20 years & \\
\hline 20 years and above & \\
\hline
\end{tabular}

Table 3: Characteristics of the Sample

The locations chosen for the interview sessions were at their workplace, namely the Kelantan Registrar's Office, Land Office of Jajahan Kuala Krai, Universiti Teknologi MARA (UiTM), Kuala Lumpur City Hall, Universiti Tun Hussein Onn Malaysia (UTHM), Universiti Teknologi Malaysia (UTM). The duration of the session was between 25 to 30 minutes. The researcher wrote notes during the session and audio recorded the interviews which later were transcribed.

\section{Interview Guide}

As this objective utilised a semi-structured interview, an interview guide was essential to assist the researcher to achieve the research objectives (Bryman, 2012). The questions used for the interview guide during the interview sessions were developed from Creswell's (2006) guidelines for developing and asking effective interview guide questions. Questions were relevant to the land allocation approach to accommodate the landless flood victims at Kuala Krai, Kelantan. The differences in answers among the participants were explored.

Exploration will be used to elicit detailed, oriented information from participants and to encourage elaboration, clarification and verification of the topics discussed (Yin, 2003). Other questions not included in this guide will be additional exploring questions (Saldana, 2009). This list of four questions was not comprehensive and only serves to achieve objective three of the research that is to recommend land allocation approach to accommodate the landless flood victims.

\section{Analysis of Data}

In analysing interview data, Kvale \& Brinkmand (2009) distinguish three processes for data analysis (Refer to Figure 3.). 


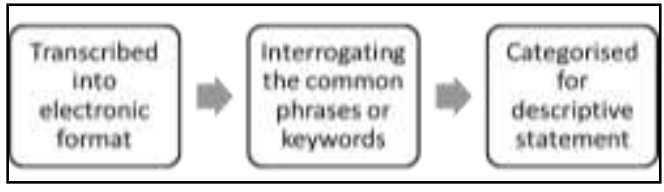

Figure 3.: Analysing Interview Data

Upon the completion of the semi-structured interviews, the researcher transcribed the interviews into electronic format (Microsoft Word). The word-to-word transcription of what the respondents said sometimes had some unfinished sentences that showed the respondents were reflecting on the question or at a pause while thinking (Creswell, 2006). It should also be noted that the analysis of objective was translated from Malay to English.

\section{Results and Discussion}

This section presents the results of a qualitative descriptive research probing the best land allocation approach for emergency, temporary shelters and post-disaster new permanent houses. Twelve experts in land law, land policies and land administration were successfully interviewed.

\section{Current approach in Kuala Krai}

The 2014 major floods had caught many by surprise, including the Kelantan government especially the Kuala Krai local government. When it comes to post-disaster management, the government will help the victims by granting them new houses, in fact in some cases also with land. However, the big scale destruction had rendered the government helpless as it involves high reconstruction cost and requires a large land area which could not be made available immediately at that critical time. [Excerpts below]

"The only issue in Kelantan is the 2014 major flood involved a large number of evacuees and destroyed houses. It is impossible for the state government to provide land for the huge number of the vulnerable groups although the federal (government) had provided new permanent houses for all the victims. So definitely the ad-hoc basis is irrelevant for that kind of situation" [N11]

In addition to that, the current approach in the management of the post-disaster new permanent house construction is that the government can only give up their land which had already been alienated for the Kelantan government's use. If the government disposes new land, the location would not be strategic; also it is remote from Kuala Krai town. Thus, some of the government land needs to be surrendered for the flood victims. Furthermore, a large part of the Manek Urai land had already been alienated to individuals and organisations, including the government. [Excerpts below]

"...we just use the existing government land. Land that should be developed for the Kelantan Industrial Training Institute was surrendered to give priority to the flood victims." [N3]

"...if we want to give state land in Kuala Krai, 90\% had already alienated." [N7] 
Moreover, the cost for the reconstruction of the new permanent houses is very high and the state government could not afford the incurred cost. Fortunately, the Federal Government, NGOs and individuals provide new permanent houses to aid the state government. [Excerpts below]

"We (Kelantan State Government) can only provide the land. The state government could not afford to develop all the houses. The estimated minimum cost of a house is about RM 40,000, 00. Multiply that by 1,800 registered victims. Meaning RM 72 Million must be spent. If you want to make it available to all immediately, the state government cannot provide." [N6]

"....houses for the victims without land ownership were sponsored by the Federal Government, Selangor State Government, individual contribution from Tan Sri Muhyiddin Yassin, and also contribution from the Kelantan Islamic Religious Council (MAIK)." [N4]

It is only two years later that the state government was able to resettle the non-registered proprietor flood victims. The resettlement locations are in Kampong Telekong Batu Jong and Sungai Durian which are still in the Kuala Krai territory. [Excerpts below]

"...two projects [resettlement programmes] were carried out on the state and federal lands. State government projects in Telekong, while the federal government projects were located in two locations which are near to the factory in Staponal [Batu Jong] and Sungai Durian. The land belongs to the state government."[N4]

As the process to make the land allocation policy takes time to come into force, the participants recommended that existing government lands which are not being developed to be allocated for the purpose of emergency, temporary shelters and post-disaster house construction. [Excerpts below]

"Make land available before disaster strikes. In Pakistan, the 2005 earthquake for example, a lot of land government-owned was made available quickly for temporary shelters after the disaster. Some NGOs actually bought land specifically to be used for temporary and permanent shelter in the post-disaster context." [N3]

"... a 10 acre-land owned by the "Kementerian Dalam Negeri" which was disposed for a police station is not being developed for more than 10 years. It would be best if it is allocated for emergency purposes." [N5]

"To prevent the land [existing undeveloped government land] from being unproductive or under developed, maybe it can be used to relocate the flood victims or a place for temporary shelters." [N8] 


\section{Land Allocation Approach Recommendation}

The review in Chapter Two presents that there are two possible approaches that can be applied in Malaysia to allocate land for emergency, temporary shelter and post-disaster house construction for the vulnerable groups (the landless, poor, disabled, indigenous and elderly). They are state alienation with accordance to Section 42 of the National Land Code 1965 and land acquisition under the provision of Section 3 of the Land Acquisition Act 1960. From the content analysis, all the participants claimed that state alienation under Section 42 of the National Land Code 1965 is the best approach for such purpose. Two participants mentioned the Section 2 under the List 2 of the $9^{\text {th }}$ Schedule of the Federal Constitution that articulates the land matters are under the jurisdiction of the state government. The other participant further added that as land is a state matter, the Federal Government cannot intervene in making land allocation for the said purpose. Above all, it is legally permissible for the government to allocate land for the purpose. Below are the excerpts from the selected participants. [Excerpts below]

"Look at Section 2 under the $9^{\text {th }}$ Schedule. The Federal Constitution states that any state land is under the power of the state government. If the preface you gave me on the email earlier that the ways to provide land for disaster are acquisition and state disposal, I think the state should be responsible to provide land for disaster purpose." [N10]

"Land is a state matter. So legally, to make land available for the purpose of disaster [referring to the land allocation for emergency, temporary shelters and new permanent houses] is possible by the state [government]."[N3]

"In my opinion this is the best approach because the state land is owned by the state government. So it can be disposed by alienation to the flood victims, and the process will be not complicated." [N7]

"Legally, to make land available for the purpose of disaster [referring to the land allocation for emergency, temporary shelters and new permanent houses] is possible by the state [government]. [N12]

One of the participants said that Kelantan is governed under the National Land Code 1965 and with accordance to Section 40 of the Code; it has the power to alienate land for many purposes as stipulated under the Section 42 of the Code [Excerpted below]. [Excerpts below]

"The first thing is if you go way back to the Malaysia land law, land is under the state's power. The power is written under the Section 40 of the National Land Code [1965]. You see, land law in Peninsular [Peninsular states] is governed under the National Land Code. When it comes to alienation of land, state [government] has the right to dispose land for reservation of land and other rights under Section 42 of the Code."[N4]

Besides, the state government must take care of its people's quality of life and must not let them stay in the temporary shelters for a long time which will make them more vulnerable, not less. This is because the temporary shelters do not last for a long time, also the shelters are 
erected on someone else's land and the settlers are at risk of eviction if they keep staying on that land. [Excerpts below]

"I think land allocation for such purpose should be provided by the state government [state alienation through disposal of land]. It's their people; they need to have a holistic approach in the post-disaster housing construction." [N6]

"Take temporary shelters as an example. Most of the temporary shelters in Kuala Krai are built for temporary purpose, but the constructions of new homes for the victims are taking far longer time than necessary because of land issues. This makes the victims who are landless expose to eviction by the land owners."[N11]

Equally important, all participants agreed that state alienation costs less, is quicker and less paperwork is involved than the land acquisition approach.

"If you compare state disposal [alienation] and the second approach [land acquisition], the cost is greater if acquisition is chosen. Because it will involve the affected persons or bodies whom their lands are being acquired, the scheduled land must be adequately compensated." [N1]

"It would be hassle free in terms of land administration and also involve less cost if the state government provides land for post-disaster context with the existing reserved state lands"[N2]

"If we use the land acquisition approach, the cost will be high."[N3]

"Theoretically we can use this approach, but it will involve a significantly higher cost."[N4]

"Land acquisition approach will be quite difficult because it involve other people's land."[N5]

"Approach of land acquisition will incur high cost and is time consuming..." [N6]

On the whole, it is favoured that state alienation is the best land allocation approach for emergency, temporary shelters and post-disaster new permanent house construction. It is legally permissible, technically executed, costs less and quick. However, some improvements need to be done to acknowledge the land allocation for emergency, temporary shelters and new permanent house purpose is the state's jurisdiction.

"Such land [emergency, temporary shelters and new permanent houses] can be made available under Section 62 that says the state can reserve any of the state land for public purposes, however it must comply with the Section 62(2) requirements. The reservation must be detailed, the purpose...the "public purpose" term. It is not written in the Code. Well in this case..., for disaster purpose." [N3] 
"...because the law allows the state [government] to do so. Above all, land belongs to the state [government]. Next thing is the state [government] has the power to dispose land for land reservation and ownership of land." [N2]

"But for disaster context, does the reservation of land under section 62 allow any of the state lands to be reserved for emergency disaster purpose?" [N9]

"...relevant bodies need to propose the existing law to be amended to include the emergency, [temporary] shelters and new [permanent] homes as public purposes. Except if there are already existing cases of law that had already interpreted such purpose as public purpose." [N8]

\section{The Need for Land Allocation Policy and Modifications}

To begin with, a land allocation policy must come into force. The participants addressed that with the land allocation policy; land can be made available before a disaster strikes. This will immediately assist vulnerable groups such as the elderly, disabled and victims without land ownership in the post-disaster house construction. The participants were also concerned with the victims who built temporary shelters on private or state land who will be evicted if the process to acquire land takes a long time. [Excerpts below]

"The existing legal framework is not particularly helpful or well written when it comes to renters. Because of this problem, (the) policy in the post-disaster housing construction must be enhanced (so) that (it) will include all disaster victims irrespective of their land titles." [N3]

"I would also suggest, if possible, identify plots of land for temporary use beforehand. This is all pre-disaster land policy planning". [N4]

"Land allocation policy must be introduced in the resettlement framework. What worries me is most of the temporary shelters in Kuala Krai are built for temporary purpose, but the constructions of the new homes for the victims are taking far longer than necessary because of land constraints. But if the government has allocated land for emergency; all the aids, shelters and post house construction can be immediately provided and the landless victims will be not overlooked." [N10].

Secondly, the resettlement programme must take into consideration the fact that the houses could be sold after the victims obtained the land and the new permanent houses. The government can endorse a caveat for a period of time, such as 10 years, to prevent any dealings. The house must also be occupied by the victims. Any rental activities must be prohibited. This is to ensure that those who receive the houses are eligible.

"...they need to stay there for more than five or six years to prevent the occurrence of buying and selling in a short time period. The alienated land must be inserted with (a) caveat up to 10 years." $[\mathrm{N} 5]$ 
"Most importantly we have to make sure that the person who receives this land is really eligible to avoid fraudulent people who take advantage of the mercy of the state and federal provisions."[N7]

Another highlight is that the land allocated for such purpose must be strategic, safe and has access to facilities such as schools, grocery stores and health care. This is because currently the resettlement for the 2014 flood victims is situated at flood prone areas and is remote from Kuala Krai Town. This will discourage victims to settle at the designated place.

"The evacuation area is still an area at risk of flooding. Federal land [resettlement for 2014 flood victims] in Sungai Durian was also affected by the floods in year 2014. The Telekong resettlement programme is also a flood-prone area, also located remote from the town [Kuala Krai] as it is near the forest reserved land." [N4]

\section{Conclusion}

All experts recommended state alienation for the land allocation approach to accommodate the non-registered proprietor flood victims at Kuala Krai, Kelantan. The justifications for the recommendations are as follows:

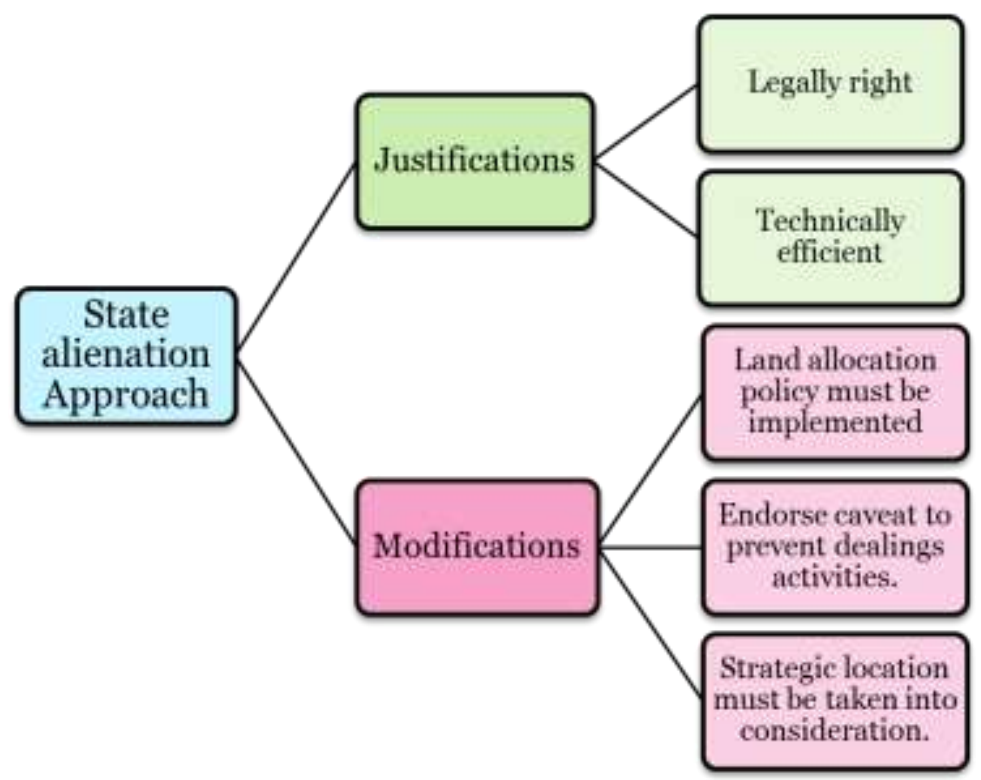

Figure 4: The Recommended Land Allocation Approach For Emergency, Temporary Shelters and Post Disaster House Construction in Kelantan

- Land is a state matter.

- The state has the power to dispose land for reservation, in this case reserve for public purpose under resettlement programmes.

- It costs less and takes a shorter time than the acquisition of land for land allocation.

The availability of land will allow the immediate start of the post-disaster new permanent house construction in the resettlement areas. The state land is under the State Authority's jurisdiction as provided under the Federal Constitution (List 2 Ninth Schedule). If the state 
government can dispose land under the reservation of land, it is also possible for it to dispose land for the purpose of post-disaster house construction and the land allocation for emergency, temporary shelters and new permanent houses. This approach will provide land banking for emergency. In Pakistan (the 2005 earthquake) and India (the 2001 Gujarat earthquake), for example, a lot of land was government-owned and made available quickly after the disaster for temporary shelters. Moreover, some NGOs actually bought land specifically to be used for temporary and permanent shelter in the post-disaster context.

However, some concerns and modifications need to be addressed as stressed by the participants during the interview sessions. Firstly, the governments must have land allocation policy in the resettlement framework. This will enhance the disaster management from all levels, especially in handling the post-disaster context or the rehabilitation and reconstruction phase. Take temporary shelters as an example. Most of the temporary shelters in Kuala Krai during the 2014 major floods were built for temporary purpose, but the construction of the new permanent houses for the victims took far longer time than necessary because of land ownership constraints. This makes the victims who are without land ownership is exposed to eviction by the land owners.

Secondly, prior to the award of land and new permanent houses, a restriction in interest must be endorsed to prevent any dealings by the victims once they have obtained the new houses. For instance, a caveat of 10 years can be endorsed on the title to prohibit buying or selling. Possibly, in terms of the selection of a person who is to receive the new permanent house need to be improved. If possible, make sure that people who will receive the land are the eligible persons because there is a lot of political intervention in this process. Undeniably, some victims who are not eligible for the new permanent houses will still get the house with the help of "invisible hands". This dishonest behaviour must be eliminated to ensure only genuine victims receive the new permanent houses and new land.

Finally, the resettlement area must consider livelihood assistance or opportunities like new accessibility to road communications, public transportation, health facilities, police station, schools et cetera. In simpler terms, strategic locations must be considered for the resettlement programmes. Where resettlement projects are moving forward, for example in Telekong Resettlement area, the site is remote from Kuala Krai town. It is also far from schools and social networks. It takes 35 minutes to Kuala Krai town. According to one of the MERCY staff, the main complaint of people is the location of the resettlement site. However, on the positive side, the local government, with the support of the federal government, Lembaga Zakat Selangor and the state government plan to implement a comprehensive livelihood programme for resettled families and establish a new "economic centre" in the area. However, it appears that the current physical relocation is taking place in the absence of sufficient livelihood assistance or pre-flood livelihood opportunities like new markets are not in place.

The flood risks cannot be eliminated despite many mitigation programmes which have been executed by both federal and state governments. Thus, this land allocation approach through state alienation of land is a forward looking approach in post-disaster management. 
INTERNATIONAL JOURNAL OF ACADEMIC RESEARCH IN BUSINESS AND SOCIAL SCIENCES

Vol. 8, No.1, January 2018, E-ISSN: 2222-6990 @ 2018 HRMARS

\section{Acknowledgement}

The researchers would like to extend gratitude to Ministry of Finance for granting us funding under National Property Research Grant (NaPReC) to venture into this research and for unwaveringly supportive throughout the term of the research.

\section{References}

Husin, A. A. (1996). Undang-undang Pemerolehan dan Pengambilan Tanah. Kuala Lumpur: Dewan Bahasa dan Pustaka.

Saraf, M. H. M., Mohd, T., \& Pin, S. F. C. (2018). Land Allocation Approach for the NonRegistered Proprietor Flood Victims in Kuala Krai. International Journal of Academic Research in Business and Social Sciences, 8(1), 940-956. 